\title{
Investigating Activated Sludge Microbial Population Efficiency in Heavy Metals Removal from Compost Leachate
}

\author{
Mehrdad Farrokhi, ${ }^{1,2}$, Mohammad Naimi-Joubani², Abdollah Dargahi", \\ Mohsen Poursadeghiyan ${ }^{1}$, Hamzeh Ali Jamali ${ }^{4 *}$ \\ ${ }^{1}$ Research Center in Emergency and Disaster Health, University of Social Welfare and Rehabilitation Sciences, \\ Tehran, Iran \\ ${ }^{2}$ Research Center of Health and Environment, Guilan University of Medical Sciences, Rasht, Iran \\ ${ }^{3}$ Department of Environmental Health Engineering, School of Public Health, Kermanshah University \\ of Medical Sciences, Kermanshah, Iran \\ ${ }^{4}$ Environmental Health Department, School of Health, Qazvin University of Medical Sciences, \\ Qazvin, Iran
}

Received: 17 June 2017

Accepted: 23 July 2017

\begin{abstract}
Solid waste production has increased in recent years. Many studies have shown that generated leachate from solid waste contains a high concentration of heavy metals. Their removal efficiency from leachate was investigated in aerobic suspended and attached growth systems in lab-scale within 72 hours of aeration. All of the materials used were analytical grade (Merck). Maximum efficiency of the attached growth system in removal of $\mathrm{BOD}_{5}$ and $\mathrm{COD}$ was, respectively, $80 \%$ and $78.28 \%$. Maximum removal efficiency for both attached and suspended growth was related to lead, and minimum removal efficiency was related to vanadium for the attached growth, and cadmium for suspended growth. Heavy metals removal efficiencies in attached growth from max to min were lead, iron, manganese, cobalt, zinc, mercury, magnesium, copper, chromium, nickel, cadmium, and vanadium, respectively; and the removal efficiencies for suspended growth from max to min were lead, manganese, iron, zinc, copper, magnesium, cobalt, mercury, chromium, nickel, vanadium, and cadmium, respectively. Generally it can be concluded that both systems are suitable for young leachate treatment, but to satisfy environmental discharge standards post treatment will be necessary.
\end{abstract}

Keywords: microbial population, activated sludge, heavy metals, leachate

*e-mail: jamalisadraei@yahoo.com 


\section{Introduction}

In recent years solid waste production has increased, generally due to increasing population and urbanization coupled with changes in consumption patterns and overuse of resources. Today the high production of solid waste is a global crisis [1-2].

One of the most environmentally sound methods for solid waste disposal is composting. In this method solid wastes undergo aerobic or anaerobic degradation and are converted to organic compost that will be useful in agricultural activities. Composting is a good alternative for sanitary landfills in an area with high groundwater levels [3-4]. Guilan Province is located on the southern side of the Caspian Sea and includes various internationally registered natural resources such as wetlands, lakes, rivers, forests, etc. Improper waste management will have adverse effects on these natural resources and public health [5-6].

There is an artificial composting plant in the city of Rasht (the capital of Guilan) with a capacity of 250 Ton/day. Leachate from the composting plant is one of the most important subjects from environmental and public health points of view in this city. Leachate can be defined as a high-strength organic wastewater that contains a high concentration of recalcitrant organics and toxic mineral matter such as heavy metals. When untreated leachate is discharged directly to the environment it may adversely affect the environment and health $[5,7]$.

Many studies show that generated leachate from solid waste contains a high concentration of such heavy metal as $\mathrm{Cu}, \mathrm{Cd}, \mathrm{Cr}, \mathrm{Hg}, \mathrm{Pb}, \mathrm{Zn}, \mathrm{Ni}, \mathrm{Fe}, \mathrm{Co}$, etc. The sources of heavy metals in leachate can be industrial waste as well as municipal solid waste containing electronic waste, pesticides, fluorescent lamps, thermometers, batteries, and other similar materials [8-9]. It is known that concentration of Heavy metals in young leachate is greater than old one. The toxic effects of heavy metal on human health is clearly known. Exposure to heavy metals may occur through diet, from medications, from the environment, or in the course of work or play. Pollution of water and soil by untreated leachate can play an important role in human exposure to heavy metal [9-10]. In recent years, various methods for heavy metal removal from wastewater have been extensively studied. Chemical precipitation, ion exchange, nano technology, adsorption, and biological methods are commonly used for heavy metal removal $[6,11]$. The $\mathrm{COD}$ of young leachate is 30-40 times greater than municipal wastewater with a high $\mathrm{BOD}_{5} / \mathrm{COC}$ ratio $(>0.6)$ and high concentrations of low molecular weight organics. Therefore, biological treatment methods (anaerobic and aerobic) are commonly applied for treating young leachate. Activated sludge processes are commonly used for treating all type of wastewater, including leachate. One of the most important limitations of this process for leachate treatment is the effect of toxic substances such as heavy metals on microbial populations, which leads to many difficulties in operating activated sludge processes and may result in unsatisfied discharge to the environment [12-13].

The main objectives of this study were evaluating the contemporaneous removal potentials of heavy metals, $\mathrm{BOD}_{5}$, and COD of activated sludge biomass and comparing attached and suspended biomass efficiencies.

\section{Materials and Methods}

This study was conducted on real leachate and sludge at lab scale in the laboratory of wastewater microbiology of Guilan University of Medical Sciences. Initial sludge was collected from the return sludge line of the activated sludge plant operated in Lahijan industrial complex in northern Iran. Raw leachate collection was done from the Guilan composting plant. The collected leachate was stored in a plastic bottle at $4^{\circ} \mathrm{C}$ until use. The maximum retention time of sample storage was one week.

\section{Analytical Methods}

All chemicals were purchased from MERK (Germany) and the purity of chemicals was $98 \%$ and higher. Initial $\mathrm{pH}$ of mixed leachate and sludge was adjusted using 0.1 normal $\mathrm{HCl}$ and $\mathrm{NaOH}$ on 7 and monitored with an 826 Metrohm $\mathrm{pH}$ meter. Dissolved oxygen concentration in the aeration jar was determined with an HQD (4od) probe DO meter from HACH Company. All other analysis included: $\mathrm{COD}, \mathrm{BOD}_{5}$, and VSS, were conducted according to standard methods for water and wastewater examination [14]. The biomass was estimated by measuring volatile suspended solids (VSS) according to the method of $2940 \mathrm{E}$ in standard method. Heavy metals concentration in the digested sample was determined by inductive coupled plasma-optical emmision mass spectrometry (ICP) (Amitec Arcos spectrometer), according to standard methods for water and wastewater examination.

\section{Experimental Setup}

Two glass jars of 10-1 volume were used as batch aeration reactors - one for suspended growth and the other for attached growth experiments. Diffused aeration using a centrifuge blower and pipe diffuser was performed. Aeration times of 24, 48, 72, 120, and 360 hours were selected for each reactor, and the aeration experiment was repeated three time for each retention time. The mixing ratio of the leachate and activated sludge was 1/1 (3-1 leachate/3-1 sludge). A spherical poly propylene media with $55 \mathrm{~mm}$ diameter and specific surface of $300 \mathrm{~m}^{2} / \mathrm{m}^{3}$ was used as fixed media in the attached growth reactor. Geometric means were calculated using Excel.

\section{Results and Discussion}

Leachate qualitative characteristics were COD 38,500 $\mathrm{mg} / \mathrm{L}$, BOD5 22,000 mg/L, pH:7.45, EC 50 (msec/cm); 


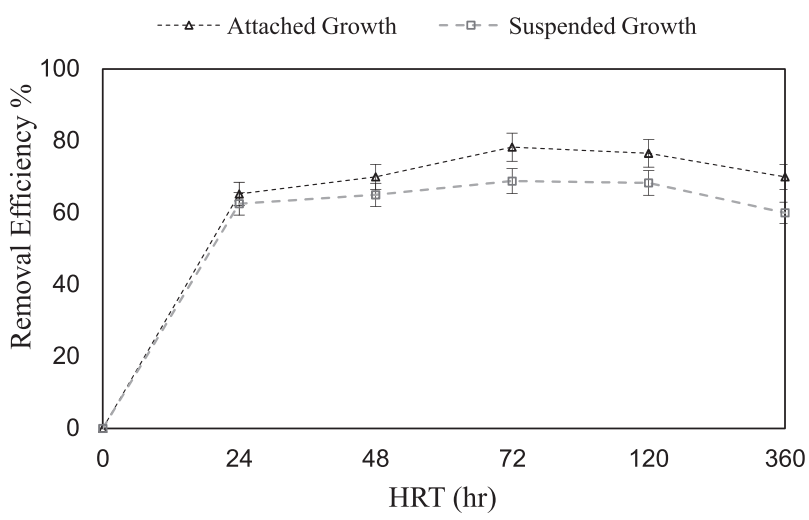

Fig. 1. $\mathrm{BOD}_{5}$ removal efficiency in suspended and attached growth.

heavy metals as: $\mathrm{Pb} 0.68, \mathrm{Mn} 141.5, \mathrm{Fe} 999, \mathrm{Zn} 121.2$, $\mathrm{Cu}$ 2.57, Mg 736, Co 3.47, $\mathrm{Hg}$ 0.74, Cr 18.56, Ni 16.52, V 0.68 , and Cd $2.23 \mathrm{mg} / \mathrm{L}$. High concentrations of COD and $\mathrm{BOD}_{5}$ can be seen and from the other hand the mean $\mathrm{BOD}_{5} / \mathrm{COD}$ is about 0.6 , which indicates that it is a biodegradable solution and biological processes are appropriate for treatment of this leachate because of a higher fraction of biodegradable organic material.

\section{$\mathrm{BOD}_{5}$ and COD Removal}

Fig. 1 shows $\mathrm{BOD}_{5}$ removal efficiencies in attached and suspended growth reactors in different aeration times. As shown in Fig. $1, \mathrm{BOD}_{5}$ removal efficiencies build up with aeration time increasing in both suspended and attached growth. The maximum $\mathrm{BOD}_{5}$ removal efficiencies were $78.3 \%$ and $68.8 \%$ in aeration time of $72 \mathrm{hr}$ for attached and suspended growth, respectively.

COD removal of leachate in suspended and attached growth reactors are shown in Fig. 2. It can be seen as the same as $\mathrm{BOD}_{5}$, with removal efficiencies of COD improved with aeration time increasing in both suspended and attached growth, and maximum removal was obtained in a 72-h aeration time. Maximum COD removal efficiencies were $80 \%$ and $75.8 \%$ for attached

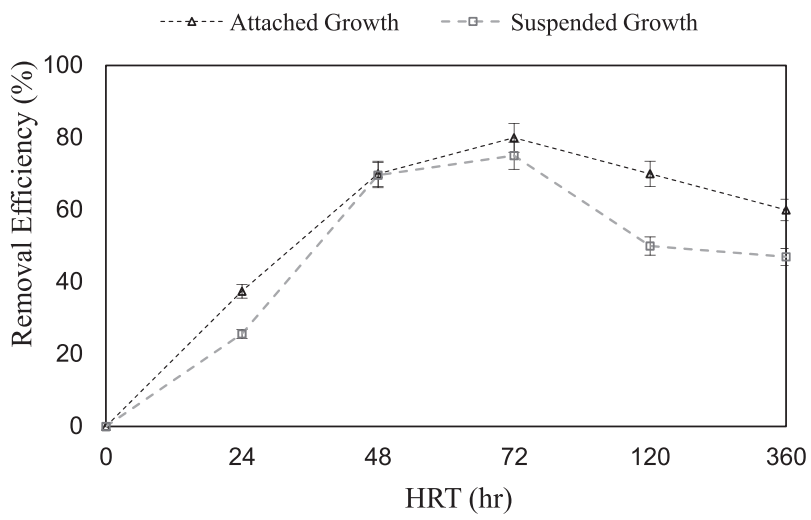

Fig. 2. COD removal efficiency in suspended and attached growth. and suspended growth, respectively. These results were consistent with the Kheradmand et al. study [15] and Amin et al. [16]. Amin et al. studied a complementary treatment of leachate using a sequencing batch reactor (SBR). The results showed that COD removal efficiency increased up to $70 \%$ in a bioreactor with time increase in all experiments [16].

A comparison of average COD removal efficiencies at different HRTs between attached growth and suspended growth shows that in all studied HRTs, the removal efficiency of attached growth was significantly greater than suspended. It should be considered that this efficiency is comparable with chemical oxidation methods such as Fenton reagent and other advanced oxidation methods [17-18]. Many studies have indicated that efficient COD removal of leachate needs integrated chemical and biological methods. Also, there are other studies that report that with young leachate more than $95 \%$ of COD can be removed [19]. On the other hand, many studies show that anaerobic processes are more efficient than aerobic ones and, for example, a Hasani et al. study indicates COD removal about $90 \%$ by anaerobic bio filters [20]. Analysis of results from Figs 2 and 3 shows that the attached growth system is more efficient than suspended growth in COD and $\mathrm{BOD}_{5}$ removal.

Differences between averages of removal efficiencies of attached and suspended growth were 7.06\% and 9.96\% for $\mathrm{BOD}_{5}$ and $\mathrm{COD}$, respectively. Comparison of observed differences between $\mathrm{BOD}_{5}$ and $\mathrm{COD}$ removal efficiencies of attached growth and suspended growth implies that a considerable point can be found. Differences between COD removal are greater than $\mathrm{BOD}_{5}$ removal, and the same pattern was observed in all hydraulic retention times except $42 \mathrm{hr}$, therefore it can result that attached growth has more ability for degradation of slowly biodegradable or recalcitrant compounds.

\section{VSS Variation}

VSS variation in duration of experiments is shown in Fig. 3. It can be seen that the final VSS concentration in attached growth is more than that of suspended growth,

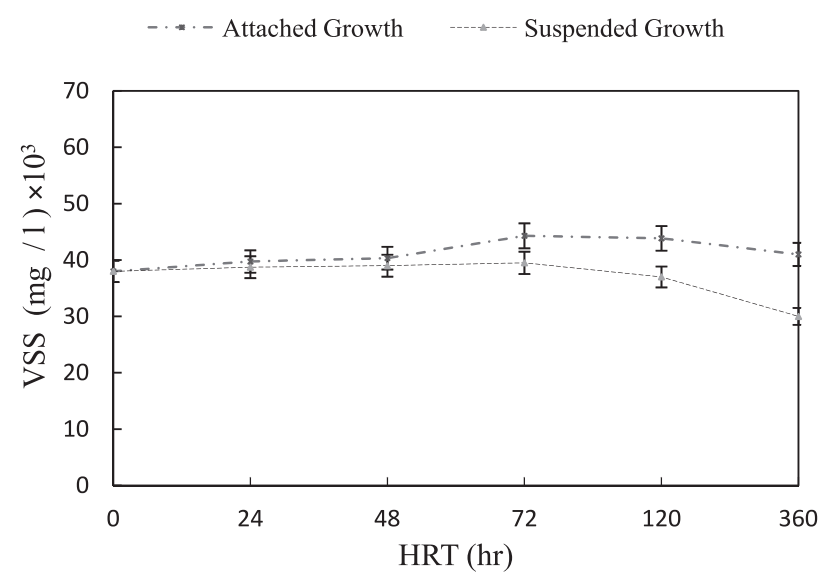

Fig. 3. VSS variation in suspended and attached growth. 
and after $120 \mathrm{hr}$ aeration time VSS concentration dropped in both systems, especially in suspended growth. This is according to the removal efficiencies of $\mathrm{BOD}_{5}$ and COD that decreased after $120 \mathrm{hr}$. As shown in Figs 1 and 2, the maximum removal efficiencies of $\mathrm{BOD}_{5}$ and $\mathrm{COD}$ occurred in aeration times of $120 \mathrm{hr}$. This is according to results of Cevat et al. that studied leachate of Istanbul landfill [21]. This may be due to the fact that with increasing aeration time, available substrate for biomass decreases and the microbial population shifts to the endogenous respiration phase, and yield coefficient and biomass formation consequently decrease [13, 22].

This point must consider that the differences between removal efficiencies may be due to different mean cell residence times (MCRT) in attached growth and suspended growth. There was no wasted sludge in both systems, and with attention to higher concentrations of VSS in attached growth it must be expected that MCRT in attached growth was often greater than in suspended growth.

\section{Heavy Metals Removal}

The trends of heavy metals removal efficiency in attached growth are given in Fig. 4, which shows that maximum removal efficiency is related to lead that is $95.3 \%$ and occurs at an aeration time of 48 hours. On the other hand the minimum removal efficiency is related to vanadium at the same aeration time (30.9\%).

Heavy metals removal efficiencies in attached growth from max to min is:

\section{$\mathrm{Pb}>\mathrm{Fe}>\mathrm{Mn}>\mathrm{Co}>\mathrm{Zn}>\mathrm{Hg}>\mathrm{Mg}$ $>\mathrm{Cu}>\mathrm{Cr}>\mathrm{Ni}>\mathrm{Cd}>\mathrm{V}$}

Fig. 5 shows that in 48 hours of aeration time, maximum and minimum removal efficiencies in suspended growth reactor are related to lead $(95.6 \%)$ and cadmium (18.8\%), respectively. This result can be due

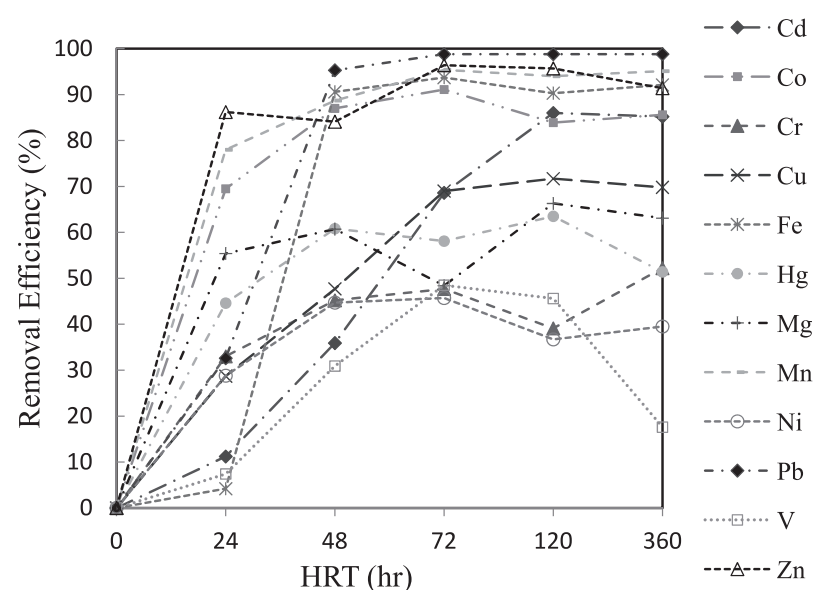

Fig. 4. Heavy metal removal efficiency in attached growth system.

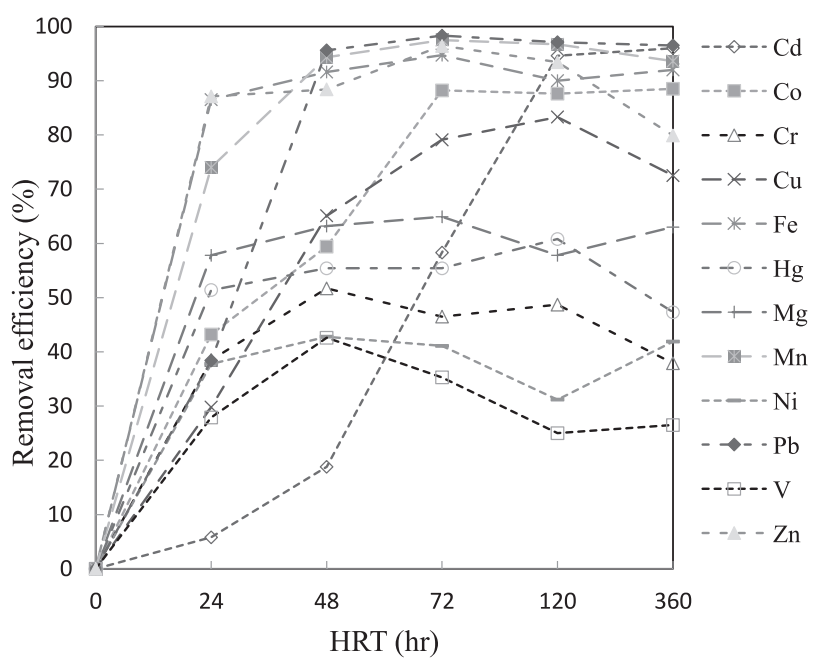

Fig. 5. Heavy metal removal efficiency in suspended growth system.

to the report of Paganelli et al. that indicated cadmium removal mechanism in activated sludge is bio-sorption, while lead was mainly removed by precipitation [23]. Heavy metals removal efficiencies in suspended growth from $\max$ to $\min$ is:

\section{$\mathrm{Pb}>\mathrm{Mn}>\mathrm{Fe}>\mathrm{Zn}>\mathrm{Cu}>\mathrm{Mg}>\mathrm{Co}>\mathrm{Hg}$ $>\mathrm{Cr}>\mathrm{Ni}>\mathrm{V}>\mathrm{Cd}$}

Results of this study agree with Hasani et al. that reported chromium, lead, and nickel removal efficiencies in the fixed activated sludge at concentrations of $1 \mathrm{mg} / \mathrm{lit}$ of heavy metals were $84 \%, 75 \%$, and $80 \%$, respectively. Similar results were obtained by Koc et al., who indicated that leachate treatment by activated sludge decreased lead concentration (75\%) but did not effect cadmium concentration [24]. Results of this study are approximately supported by Justyna et al. [25] and Cecen et al. [26], who reported that activated sludge had a high biosorption capacity and that equilibrium was reached in a short time with respect to copper, iron, manganese, zinc, and chromium, and manganese became very concentrated on activated sludge with time. Also, similar observations were reported by Hashemi et al. [27], who showed that maximum and minimum removal efficiencies of heavy metals from composting leachate were for $\mathrm{Pb}$ and $\mathrm{Cd}$, respectively [27].

A comparison of heavy metal removal efficiencies in attached and suspended growth at different aeration times shows approximately proper efficiency for heavy metal removal in both systems. With attention to Figs 4 and 5 in the initial time of aeration, removal efficiencies of systems are negligible. This can be due to that adaptation of microbial populations of activated sludge to leachate.

Removal efficiency can improve until aeration time reaches 120 hours. After this cutoff point, removal efficiencies decreased, which can be due to decreasing VSS. 


\section{Conclusions}

From results of this study we can conclude that both systems are suitable for young leachate treatment, but the attached growth system is more efficient than suspended growth for COD elimination. Also, it is concluded that both systems have proper efficiencies for heavy metal removal from young leachate, but post-treatment will be necessary to satisfy environmental discharge standards.

\section{Acknowledgements}

The authors gratefully thank the experts of the Laboratory of Wastewater of Health School of Guilan Province for their valuable contributions.

\section{References}

1. ABDULHUSSAIN A.A., GUO J., LIU Z.P., PAN Y.Y., WISAAM S. Review on Landfill Leachate Treatments. American Journal of Applied Sciences,. 6, 4, 2009.

2. NURISEPEHR M., JORFI S., REZAEI R., AKBARI H., DARVISHI R., SOLTANI C., SAMANEH M. Sequencing treatment of landfill leachate using ammonia stripping Fenton oxidation and biological treatment, Waste Management \& Research, 30, 9, 2012.

3. CAKMAKCI M., EYDA OZYAKA V. Aerobic composting leachate treatment by the combination of membrane process, Waste Management \& Research, 31, 2, 2013.

4. MOUSSAVI G., TALEBI S., FARROKHI M., MOJTABAEE SABOUTI. Removal of ammonium from water by adsorption onto synthetic zeolites $\mathrm{NaA}$ and $\mathrm{NaX}$ : A comparative parametric, kinetic, and equilibrium study. Desalination and Water Treatment. 51, 28, 2013.

5. FARROKHI M., HAJRASOLIHA M., FAHIMINIA M., TALEBI M., KOHANSAL M. The creation of management systems for funding priorities in wastewater project in rural communities in the Islamic Republic of Iran. Water Science and Technology 58, 6, 2008.

6. FARROKHI M., MESDAGHINIA A.R. Removal of 3-monochlorophenol in anaerobic baffled reactor. Journal of Applied Sciences. 7, 12, 2007.

7. WARD M.L., BITTON G., TOWNSEND T. Heavy metal binding capacity (HMBC) of municipal solid waste landfill leachates. Chemosphere. 60, 2, 2005.

8. MLI W., ZHOU Q., HUA T. Removal of Organic Matter from Landfill Leachate by Advanced Oxidation Processes: A Review. International Journal of Chemical Engineering. 2010, 2010.

9. DARGAHI A., GOLESTANIFAR H., DARVISHI P., KARAMI A., HASAN S.H., POORMOHAMMADI A., BEHZADNIA A. An Investigation and Comparison of Removing Heavy Metals (Lead and Chromium) from Aqueous Solutions Using Magnesium Oxide Nanoparticles. Pol J Environ Stud. 25, 2, 2016.

10. ASHWORTH D., ALLOWAY B. Soil mobility of sewage sludge derived dissolved organic matter, Copper, Nickel and Zinc. Environ pollut,. 127, 1, 2004.

11. FARROKHI M., HOSSEINI S.C., YANG J.K., SHIRZADSIBONI M. Application of $\mathrm{ZnO}-\mathrm{Fe}_{3} \mathrm{O}_{4}$ nanocomposite on the removal of azo dye fromaqueous solutions: Kinetics and equilibrium studies. Water Air Soil Pollut. 225, 2014

12. KEWU P., WENQI G. Biodegradability enhancement of municipal landfill leachate. Water Science and Engineering,. 1, 4, 2008

13. JAFARI J., MESDAGHINIA A., NABIZADEH R., FARROKHI M., MAHVAI A.H. Investigation of anaerobic fluidized bed reactor/ aerobic moving bed bio reactor (AFBR/MMBR) system for treatment of currant wastewater. Iranian Journal of Public Health. 8, 42, 2013.

14. APHA A., WWA W. Standurd Methods for the examination of water and wastewater. Washington DC, : American Public Health Association. 3030D, 2012.

15. KHERADMAND S., KARIMI-JASHINI A., SARTAJ M. Treatment of municipal landfill leachate using a combined anaerobic digester and activated sludge system. Waste Management. 30, 2010.

16. AMIN M.M., HASHEMI H., BINA B., EBRAHIMI A., POURZAMANI H.R. Complementary treatment of leachate using sequencing batch reactor. Int J Health Syst Disaster Manage. 2, 2014

17. FARROKHI M., DINDARLOO K., JAMALI H.A. Optimization of fenton oxidation process for biodegradability enhancement of a mature landfill leachate using response surface methodology. Research journal of environmental toxicology. 9, 6, 2015.

18. HOSSAINI H., MOUSSAVI G., FARROKHI M. Oxidation of diazinon in cns- $\mathrm{ZnO} / \mathrm{LED}$ photocatalytic process: Catalyst preparation, photocatalytic examination, and toxicity bioassay of oxidation by-products. Separation and Purification Technology. 174, 2017.

19. KURNIAWN T.A. Treatment of Landfill Leachate. 1.: LAP LAMBERT Academic publishing GmbH and Co.KG. 2011.

20. HASANI A., HESAM A., MOKHTARANI N., BAYATFARD N. Variability of leachate treatment plant Gillan and Compost Company Using anaerobic filters (with the downward and upward). Environmental Science and Technology. 11, 3, 2009.

21. CEVAT Y., OZCAN H.K., DEMIR G., OKTEN H.E., YILDIZ S., COBAN A., BALAHOLI V. Landfill Leachate Treatment: A Case Study for Istanbul City. Clean soil air water. 40, 7, 2012.

22. SETIADI T., FAIRUS S. Hazardous waste landfill leachate treatment using an activated sludge-membrane system. Water Science and Technology. 48, 8, 2003.

23. JONIDI JAFARI A., SHIRZAD SIBONI M., YANG J.K., NAIMI JOUBANI M., FARROKHI M. Photocatalytic degradation of diazinon with illuminated $\mathrm{ZnO}^{-\mathrm{TiO}_{2}}$ composite. Journal of the Taiwan Institute of Chemical Engineers, 50, 2015.

24. PAGNANELLI F., MAINELLI S., DIONISI D., TORO L. Mechanisms of heavy-metal removal by activated sludge. Chemospher. 7, 8, 2009.

25. JUSTYNA KOC J., LUKASZ J. Efficiency of removal of heavy metals from municipal landfill leachate. Journal of Elmentol. 12, 4, 2007.

26. CECEN F., GURSOY G. Biosorption of heavy metals from landfill leachate onto activated sludge. J Environ Sci Health A Tox Hazard Subst Environ Eng. 36, 6, 2001.

27. HASHEMI H., EBRAHIMI A., MOKHTARI M., JASEMIZAD T. Removal of PAHs and heavy metals in composting leachate using the anaerobic migrating blanket reactor (AMBR) process. Desalination and Water Treatment. 57, 52, 2016. 